\title{
A escrita como experiência de luta e resistência: Maria Archer
}

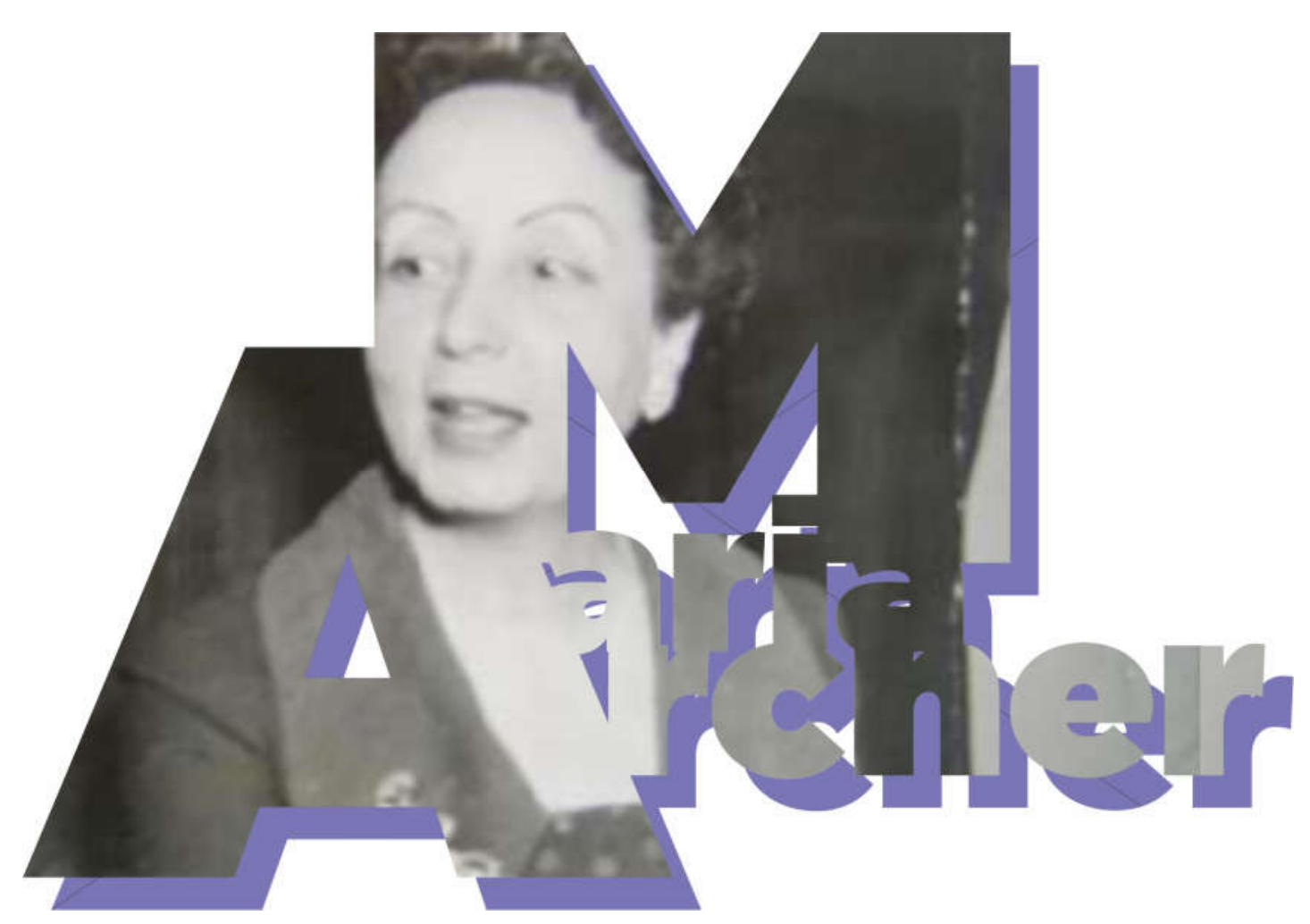

Maria Archer. Correio Paulistano, 1956, fotografia (detalhe).

\section{Maria Izilda Santos de Matos}

Doutora em História Econômica pela Universidade de São Paulo (USP) e livre-docente pela Pontifícia Universidade Católica de São Paulo (PUC-SP). Professora do Programa de Estudos Pós-graduados em História da PUC-SP. Pesquisadora do CNPq. Autora, entre outros livros, de Portugueses: deslocamentos, experiências e cotidiano - São Paulo, séculos XIX e XX. Bauru: Edusc, 2013. mismatos@pucsp.br 


\section{A escrita como experiência de luta e resistência: Maria Archer}

Writing as an experience of struggle and resistance: Maria Archer

\section{Maria Izilda Santos de Matos}

\section{RESUMO}

Este artigo focaliza o protagonismo feminino nas ações e lutas de oposição ao salazarismo, destacando a trajetória e obra de Maria Archer. Para tanto, recupera o contexto, trajetória de vida e produção de Archer em Portugal, em particular as ações de censura às suas obras; na sequência, analisa a atuação e obras produzidas nos anos de exílio em São Paulo (1955-1979). A pesquisa realizada valorizou uma diversidade de fontes e referências: a documentação da Pide (Polícia Internacional e de Defesa do Estado), o acervo da Torre do Tombo e da Fundação Mário Soares (em Portugal), do Deops/SP (Departamento Estadual de Ordem Política e Social), textos literários, cartas, fotografias, entrevistas, crônicas, imprensa, priorizando os escritos de $\mathrm{Ma}$ ria Archer no exílio.

PALAVRAS-CHAVE: exílio; antissalazarismo; Maria Archer.

\section{ABSTRACT}

This article focuses on female protagonism in the actions and struggles of opposition to Salazarism, highlighting the trajectory and work of Maria Archer. For this, the context, life trajectory and production of Archer in Portugal is recovered, particularizing the actions of censorship of her works; next, it analyzes the performance and works produced in the years of exile in São Paulo (1955-1979). The research carried out valued a diversity of sources and references: the documentation of Pide (Polícia Internacional e de Defesa do Estado), the collection of Torre do Tombo and the Fundação Mário Soares (Portugal), Deops/SP (Departamento Estadual de Ordem Política e Social), literary texts, letters, photographs, interviews, chronicles, press, giving priority to the writings of Maria Archer in exile.

KEYWORDS: exile, anti-salazarism, Maria Archer.

Vim para o Brasil, tendo chegado dia 15-07-1955, porque já não podia viver em Portugal. A ação da censura asfixiou-me e tirou-me os meios de vida. Apreenderam-me dois livros publicados, assaltaram-me com policiais a casa e levaram-me um original que ainda estava escrevendo, violência inédita em países de civilização europeia. ${ }^{1}$

Em entrevista ao Diário de Notícias, em 1956, ao se reportar à sua chegada ao exílio, no ano anterior, Maria Archer, escritora e intelectual portuguesa, denunciou as perseguições a que foi submetida em Portugal, considerando-se "amordaçada pela censura". Assim, como outros portugueses exilados

${ }^{1}$ ARCHER, Maria (entrevista). Diário de Notícias, São Paulo, 15 jan. 1956. 
em São Paulo, ela levou à frente ações de oposição ao regime salazarista, tendo como arma de luta a escrita.

O exílio² é uma situação impactante, que provoca reações e necessidade de desabafos, desencadeando desejos de preservar a memória dessa experiência através da escrita, analisando e registrando contextos, ideias e práticas políticas, redes e conexões estabelecidas, além de dilemas afetivos. ${ }^{3}$ Nesse sentido, esta investigação pretende ser uma contribuição para o estudo do protagonismo feminino nas ações e lutas de oposição ao salazarismo, pondo em destaque a trajetória e obra de Maria Archer. Para tanto, inicialmente, busca recuperar o contexto vivenciado pela escritora (o Estado Novo português e seus aparelhos repressivos); na sequência retoma a trajetória de vida e a produção de Archer em Portugal, em especial as ações de censura às suas obras. Finaliza com a análise de sua atuação e obras produzidas nos anos de exílio em São Paulo (1955-1979).

Para enfrentar tal desafio, a pesquisa lançou mão de uma diversidade de fontes e referências: a documentação da Pide (Polícia Internacional e de Defesa do Estado), o acervo da Torre do Tombo e da Fundação Mário Soares (em Portugal), do Deops/SP (Departamento Estadual de Ordem Política e Social); textos literários, cartas, fotografias, entrevistas, crônicas, imprensa, conferindo prioridade aos escritos de Archer no exílio.

\section{Estado Novo português: autoritarismo, censura e propaganda}

Em Portugal, as tensões que levaram ao final da monarquia (1910) se agravaram no pós-Primeira Guerra (1914-18), estando marcadas por dificuldades econômicas e sociais (carestia, miséria, falta de emprego), embates políticos, manifestações populares, ampliação das ações sindicais e a fundação (1921) do Partido Comunista Português). Essa conjuntura de tensões possibilitou o acesso dos militares ao poder estatal (1926).

Com a ascensão ao governo do general Fragoso Carmona, foi indicado para o Ministério das Finanças Antonio de Oliveira Salazar (1928), que, após assumir a presidência do Conselho de Ministros, norteou a estruturação do Estado Novo, implantado em 1933/34. Este se caracterizou como um "regime autoritário católico" (marcado por ações políticas corporativas, intervencionistas e alianças com a Igreja Católica), que adotou uma política econômica de manutenção de padrões tradicionais, com resistência às mudanças e à industrialização, considerada a causa dos conflitos de classe. ${ }^{4}$

\footnotetext{
${ }^{2}$ A delimitação dos significados semânticos de exílio é complexa. O termo é polissêmico, podendo significar a experiência de ser expatriado forçado ou voluntário, envolvendo o ser expulso da pátria e também o apartar, arredar, afastar-se do convívio social. Embora toda pessoa impedida de voltar para casa seja um exilado, há distinções entre exilados, asilados, refugiados, expatriados e emigrados.

${ }^{3}$ Ver SAID, Edward. Reflexões sobre o exílio. In: Reflexões sobre o exílio e outros ensaios. São Paulo: Companhia das Letras, 2005; HOCHMAN, Nicolás. Conflictos y posibilidades de los escritores en el exilio: la discusión entre Émile Cioran y Witold Gombrowicz. Anagramas-Rumbos y sentidos de la comunicación, v. 10, n. 19, Medellín, 2011; SARLO, Beatriz. Tiempo presente: notas sobre el cambio de una cultura. Buenos Aires: Siglo XXI, 2006, e ARENDT, Hannah. Homens em tempos sombrios. São Paulo: Companhia das Letras, 1988. ${ }^{4}$ Ver MAXWELL, Kenneth. O império derrotado: revolução e democracia em Portugal. São Paulo: Companhia das Letras, 2006; SECCO, Lincoln. A Revolução dos Cravos e a crise do império colonial português. São Paulo: Alameda, 2004; PAULO, Heloisa. Aqui também é Portugal: a colónia portuguesa do Brasil e o salazarismo Coimbra: Quarteto, 2000; SILVA, Douglas M. A oposição ao Estado Novo no exílio brasileiro, 1956-1974. Lisboa:
} 
Durante todo o Estado Novo, movimentos e manifestações de oposição foram reprimidos, sendo instituídos mecanismos de controle de expressão e de propaganda política do regime. ${ }^{5}$ Em 1933, foi criado o Secretariado de Propaganda Nacional (SPN), órgão ligado diretamente ao Conselho de Ministros (portanto, a Salazar). Este secretariado assumiu as funções de controlar e censurar os meios de difusão cultural, encarregando-se de fiscalizar a programação de rádio e televisão, a imprensa escrita e a produção artística (literatura, teatro, cinema, música, artes plásticas). Em paralelo, o SPN incentivava e apoiava expressões artísticas ufanistas através de apoio cultural e premiação a escritores e artistas, patrocínio às exposições, produções teatrais e cinematográficas, bem como da promoção de iniciativas de preservação do patrimônio e museus. $^{6}$

O escritor e jornalista Antônio Ferro presidiu o SPN de 1933 a 1950, tornando-se um dos mais influentes protagonistas políticos da nação. Em 1944, o tal órgão tornou-se o Secretariado Nacional de Informação, Cultura Popular e Turismo (SNI), incumbindo-se do controle/censura do setor artístico e cultural em Portugal e da imagem do país no estrangeiro. ${ }^{7}$

Salazar encontrou em António Ferro o homem ideal para a dinamização do seu projecto cultural [...]. A rádio, o teatro e o cinema nacionais foram especialmente favorecidos pela sua ação, tendo sido também ele o criador do grupo de danças Verde Gaio. Tentou aliciar e controlar a imprensa estrangeira, instalando-a num gabinete do Palácio Foz. O significado ideológico das diversas manifestações culturais do seu tempo não lhe escapava. Reflectindo, por exemplo, sobre os defeitos e qualidades do cinema português, Ferro pretendeu incentivar o "filme histórico", ao mesmo tempo que desencorajou os chamados "filmes cómicos", não apenas talvez por uma questão de gosto pessoal, mas porventura pelo incómodo do retrato social que registavam. ${ }^{8}$

Imprensa de Ciências Sociais, 2006; RAMOS, Ubirajara Bernini. Portugal Democrático: um jornal de resistência ao salazarismo publicado no Brasil. Dissertação (Mestrado em História) - PUC/SP, São Paulo, 2004; OLIVEIRA, Fábio Ruela de. Trajetórias intelectuais no exílio: Adolfo Casais Monteiro, Jorge de Sena e Vítor Ramos (1954-1974). Tese (Doutorado em História) - UFF, Niterói, 2010, e MATOS, Maria Izilda Santos de. Portugueses: deslocamentos, experiências e cotidiano - São Paulo, séculos XIX e XX. Bauru: Edusc, 2013. ${ }^{5}$ Movimentos de oposição e resistência ao salazarismo foram sufocados, merecendo menção o Levante Operário (1934), a Revolta dos Marinheiros ou Motim dos Barcos do Tejo (1936) e o Movimento de Unidade Democrática (1945-48). Ver PINTO, Antonio Costa. Os camisas azuis: ideologia, elites e movimentos fascistas em Portugal - 1914-45. Lisboa: Estampa, 1994; TORGAL, Luís Reis. Estados novos, Estado Novo. 2. ed. Coimbra: Imprensa da Universidade de Coimbra, 2009; SECCO, Lincoln, op. cit., e MATTOSO, José e ROSAS, Fernando. História de Portugal, v. 7: o Estado Novo. Lisboa: Estampa, 1998.

${ }^{6}$ Ver COELHO, José Dias. A resistência em Portugal. Porto: Inova, 1974; CABRERA, Ana. A memória e o esquecimento: a censura do Estado Novo em Portugal perante três peças de autores espanhóis. Media $\mathcal{E}$ Jornalismo, n. 12, Coimbra, 2008; FIUZA, Alexandre Felipe. Entre um samba e um fado: a censura e a repressão aos músicos no Brasil e em Portugal nas décadas de 1960 e 1970. Tese (Doutorado em História) - Unesp, Assis, 2006; RAMOS, Vitor. Breve análise da repressão à vida intelectual em Portugal. São Paulo: Paz e Terra, 1969; BAIÔA, Manuel. Censura como factor de formação e consolidação do salazarismo: o caso do noticiário sobre política internacional na imprensa (1933-1935). In: MARTINS, Fernando (org.). A formação e a consolidação política do salazarismo e do franquismo. Lisboa: Colibri, 2012, e PAULO, Heloisa. Estado Novo e propaganda em Portugal e no Brasil: o SPN/SNI e o DIP. Coimbra: Minerva, 1994.

${ }^{7}$ Ver TORGAL, Luís Reis. O modernismo português na formação do Estado Novo de Salazar: Antônio Ferro e a Semana de Arte Moderna de São Paulo. In: RIBEIRO, Jorge Martins, SILVA, Francisco Ribeiro da e OSWALD, Helena (orgs.). Estudos em homenagem a Luís António de Oliveira Ramos. Porto: Faculdade de Letras da Universidade do Porto, 2004.

${ }^{8}$ TORGAL, Luís Reis e HOMEM, Amadeu de Carvalho. Ideologia salazarista e "cultura popular": análise da biblioteca de uma casa do povo. Análise Social, v. XVIII, Lisboa, 1982. 
A divulgação do ideário e das ações governamentais ocorria através de vários veículos de comunicação, com destaque para o rádio. Na década de 1930, foi inaugurada a Emissora Nacional, com uma programação centrada na difusão da "verdadeira cultura popular", segundo o entendimento do governo. Com a mesma intenção de enaltecimento do regime, patrocinavam-se espetáculos de teatro, produções cinematográficas e musicais. Também foram criadas as Casas do Povo, Casas dos Pescadores, Fundação Nacional para a Alegria no Trabalho (FNAT) e a Junta de Ação Nacional, que promoviam ações culturais e de lazer. ${ }^{9}$

A propaganda política salazarista coordenou igualmente ações dirigidas para a comunidade de portugueses que moravam em outros países. No Brasil, essas ações foram centradas nos centros de maior presença lusitana; em São Paulo, destacou-se nessa mediação a Casa de Portugal. As estratégias de propaganda incluíam a divulgação de publicações como a Revista Portuguesa, o patrocínio de palestras, programas de rádio, projeção de filmes, e espetáculos teatrais e musicais de cunho apologético ao salazarismo. ${ }^{10}$

As obrigações que, no campo da propaganda no estrangeiro, cabiam ao Secretariado, bem como as ações que levou a cabo, incluíam a colaboração com todos os organismos portugueses de propaganda existentes no estrangeiro, tais como embaixadas, consulados e Casas de Portugal; supervisão de todos os serviços de imprensa oficiais fora do país; a realização de conferências e encorajamento do intercâmbio com intelectuais e jornalistas estrangeiros, com vista a moldar a opinião internacional, entre outros assuntos, sobre a política colonial; promoção cultural e artística de Portugal bem como do seu turismo. ${ }^{11}$

Após a Segunda Guerra, ampliaram-se as manifestações de oposição ao governo, como na ocasião das eleições à presidência (1957-58), com o sucesso da candidatura do general Humberto Delgado, que unificou as oposições e adquiriu popularidade. Contudo, as artimanhas eleitorais deram a vitória ao candidato da situação, Américo Tomás. Os conflitos se agudizavam e o regime desencadeou novas medidas de repressão através da PIDE, com a prisão de vários oposicionistas, enquanto outros, inviabilizados de manter suas atividades profissionais e políticas, optavam pelo exílio. ${ }^{12}$

Já nas décadas de 1960/70, observou-se o agravamento da situação socioeconômica com o declínio da produção agrícola e o aumento da emigração

\footnotetext{
${ }^{9}$ Ver TORGAL, Luís Reis, HOMEM, Amadeu de Carvalho e SANTOS, Graça. Política do espírito: o bom gosto obrigatório para embelezar a realidade. Media \& Jornalismo, n. 12, op. cit.

${ }^{10}$ Ver PAULO, Heloisa, Estado Novo e Propaganda em Portugal e no Brasil, op. cit., e idem, Aqui também é Portugal.op. cit.

${ }^{11}$ COTRIM, João Pedro. Tradutores e propagandistas: da tradução como ferramenta de propaganda do Estado Novo no estrangeiro e da indústria que se desenvolveu em torno desta no Secretariado da Propaganda Nacional/Secretariado Nacional de Informação. Dissertação (Mestrado em Tradução) - Universidade de Coimbra, Coimbra, 2010.

${ }^{12}$ Em diferentes ocasiões, levantes e ações de oposição ao salazarismo geraram repressões e exílios. Os levantes de 1927-28 e 1931 marcaram um primeiro fluxo de exilados para o Brasil, majoritariamente de republicanos e democratas. Entre 1940-56, manteve-se a saída de intelectuais e políticos. O endurecimento da repressão (1957/58) gerou novas ondas de exilados, tendo o Brasil como meta. Entre 1965-74, a ampliação das saídas esteva associada às guerras coloniais, ao movimento estudantil e ao surgimento de novos grupos políticos. Nesse momento, além do Brasil, outros destinos foram Marrocos, Argélia, França, Alemanha, Bélgica, Suécia e Itália. Ver MARTINS, Susana, Socialistas na oposição ao Estado Novo: um estudo sobre o movimento socialista português de 1926 a 1974. Cruz Quebrada: Casa das Letras/Editorial Notícias, 2005.
} 
(as remessas de dinheiro amenizavam as carências), generalizando-se os descontentamentos e o crescimento das oposições, inclusive devido à indiferença do regime quanto às tensões coloniais na África. Nesse contexto, as articulações das oposições com os oficiais intermediários do Movimento das Forças Armadas (MFA) culminaram na "Revolução dos Cravos", em 25 de abril de 1974. O programa político do novo governo propunha a criação de um regime democrático e pluralista e o fim das guerras na África. ${ }^{13}$

\section{Maria Archer: escrituras, resistências e lutas}

Minha obra tem sido norteada pelo princípio vital de rebater o preconceito arcaico da inferioridade das mulheres. ${ }^{14}$

A chamada oposição pode contar com as mais nobres energias da minha pena de escritora, da minha voz de conferencista, e mesmo com o meu voto de cidadã. ${ }^{15}$

Romancista e dramaturga, autora de uma ampla obra literária e jornalística, Maria Emília Archer Eyrolles Baltazar Moreira nasceu em Lisboa (1899), filha de João Baltazar Moreira Junior (funcionário do governo/Banco Nacional Ultramarino) e de Cipriana Archer Eyrolles Baltazar. Foi casada com Alberto Teixeira Passos (1921-1926); buscando independência econômica e profissional, divorciou-se em 1931. A escritora viveu em Angola, GuinéBissau, Niassa, Moçambique e no Brasil (1955-1979).

Maria Archer cursou apenas a escola primária e como autodidata adquiriu ampla cultura, se tornando escritora profissional, atuando como jornalista e publicando várias obras, que transitavam por diferentes campos do conhecimento, como história, geografia, etnografia, sociologia e antropologia. Sua escritura tinha um estilo agradável e envolvente, buscando, além de entreter, instruir, debater, informar, defender ideias e instigar o debate. ${ }^{16}$ Nas décadas de 1930 a 1950, Archer produziu uma ampla gama de escritos (livros, crônicas, peças de teatro, literatura infantil), proferiu palestras, conferências, participou de programas radiofônicos, trabalhou para vários jornais em Portugal e África.

\footnotetext{
13 Ver MAXWELL, Kenneth, op. cit., SECCO, Lincoln, op. cit., e MATTOSO, José e ROSAS, Fernando, op. cit.

${ }^{14}$ ARCHER, Maria. Revisão de conceitos antiquados. Ler, n. 7, Lisboa, out. 1952, p. 5.

${ }^{15}$ Idem, Eu... e mais eu. O Sol, n. 184, Lisboa, 11 set. 1948. Direção Geral do Livro dos Arquivos e das Bibliotecas-PIDE/DGS. Processo 131/48, SR, fls. 324.

${ }^{16}$ Considerada uma escritora esquecida, recentemente suas obras têm sido parcialmente reeditadas, despertando o interesse de vários pesquisadores. Merece menção BATISTA, Elisabeth, Entre a literatura e a imprensa: percursos de Maria Archer no Brasil. Tese (Doutorado em Letras) - USP, São Paulo, 2007; BORDEIRA Guilherme. Acerca de Maria Archer. Lisboa: Lantia, 2014; BOTELHO, Dina Maria dos Santos. "Ela é apenas mulher": Maria Archer, obra e autora. Dissertação (Mestrado em Estudos Anglo-portugueses) Universidade Nova de Lisboa, Lisboa, 1994; BOUZY, Armanda Manguito. Mémoires d'exil: Maria Archer, une femme anti-salazariste au Brésil. Cahiers d'études des cultures ibériques et latino-américaines, n. 1, Montpellier, mar. 2015. Disponível em <http://cecil-univ.eu/c1_5/>. Acesso em 10 nov. 2020; HORTA, Maria Teresa. Prefácio. In: ARCHER, Maria. Ela é apenas mulher. Lisboa: Parceria A. M. Pereira, 2001; MARTINS, Leonor Pires. Menina e moça em África: Maria Archer e a literatura colonial portuguesa". Lusotopie, v. 12, n. 1-2, Aix-en-Provence, 2005. Disponível em <http://www.lusotopie.sciencespobordeaux. fr/somma.2005.htm>. Acesso em 10 no. 2020; PEDROSA, Ana Bárbara Martins. Escritoras portuguesas e Estado Novo: as obras que a ditadura tentou apagar da vida pública. Tese (Doutorado Interdisciplinar em Ciências Humanas) - UFSC, Florianópolis, 2017, e PEREIRA, Maria La Salete Coelho de. Maria Archer entre o feminismo e o neorrealismo: uma leitura dos romances Ela é apenas mulher e Aristocrata. Dissertação (Mestrado em Teoria da Literatura e Literatura Portuguesa) - Universidade do Minho, Braga, 2008.
} 
Ela iniciou a sua carreira literária com a obra Três mulheres, em coautoria com Graça Pinto Quartim (Luanda, 1935). Já estabelecida em Lisboa, sua escritura foi intensificada. Nessa fase, priorizou temáticas sobre África, merecendo destaque o livro Viagem à roda de África (1938), com o qual recebeu o prêmio Maria Amália Vaz de Carvalho, seguido de outras obras na Coleção Cadernos Coloniais (1936 e 1938). ${ }^{17}$ A partir de 1938, com a obra Ida e volta duma caixa de cigarros, Maria Archer iniciou uma nova etapa ou pelo menos a incorporação de inovações temáticas, priorizando as questões da condição feminina, abordando assuntos polêmicos e tabus como violência doméstica, sexualidade feminina, virgindade, honra, aborto, separação, trabalho e prostituição, entre outros. ${ }^{18}$

Seus livros tiveram várias edições com boa recepção e aceitação do público. Eram inovadores e provocadores, retratavam a condição e o cotidiano femininos, criticavam práticas vigentes, perversidade das relações conjugais e falsas moralidades. Sua narrativa contemplava personagens femininas combativas, independentes e sedutoras, posicionadas entre o consentido e o proibido. Em 1938, Ida e volta duma caixa de cigarros foi "qualificado" pelos periódicos Voz e Novidades como "pornográfico". O Serviço de Censura apreendeu e proibiu a obra sob a alegação de que, com seu "caracter acentuadamente erótico, a autora compraz-se na volupia do promenor sensual, que parece ser o único objectivo". Apesar dos recursos impetrados (1939 e 1944), a censura manteve a decisão afirmando "que se julga de conveniência pública fundada principalmente na intenção de preservar leitores de formação incorrupta ou imperfeita de leituras que seriam perniciosas" ${ }^{19}$

\footnotetext{
${ }_{17}$ África selvagem (1935, pela qual foi considerada uma escritora revelação), Sertanejos, Singularidades dum país distante, Folclore dos negros do grupo Bantu e Ninho de bárbaros (1936), Angola filme (1937), Colônias piscatórias em Angola e Caleidoscópio africano (1938), Roteiro do mundo português (1940). Dentro dessa temática, merece menção a obra Herança lusíada (s./d.), com o prefácio de Gilberto Freyre, que destaca o "talento literário" da escritora. Nessas obras demonstrava conhecimentos etnográficos e fazia críticas eventuais à administração portuguesa na África.

${ }_{18}$ Cabe destacar, na produção da autora, as seguintes obras: Ida e volta de uma caixa de cigarros (1938), Há dois ladrões sem cadastro (1940), Fauno sovina (1941), Memórias da linha de Cascais (1943), Os parques infantis (1943), Ela é apenas mulher (1944, considerado seu melhor romance), Aristocratas (1945), Eu e elas, Apontamentos de romancista (1945), A morte veio de madrugada (1946), Casa sem pão (1947), O mal não está em nós e Filosofia duma mulher moderna (1950), Bato às portas da vida (1951), Nada lhe será perdoado (1952), A primeira vítima do Diabo (1954), Herança lusíada (s./d), e as peças de teatro Alfacinha, Isso que chamam amor, Numa casa abandonada, O poder do dinheiro e O leilão.

${ }^{19}$ Os relatórios da Direção dos Serviços de Censura da Pide anteriores a 1942 não estão disponibilizados nos arquivos da Torre do Tombo. No processo da obra Casa sem pão (1947) foram encontradas menções a Ida e volta duma caixa de cigarros. Direção Geral do Livro dos Arquivos e das Bibliotecas-PIDE/DGS. Processo 3540/1947 e Relatório da Censura 2971/1947.
} 

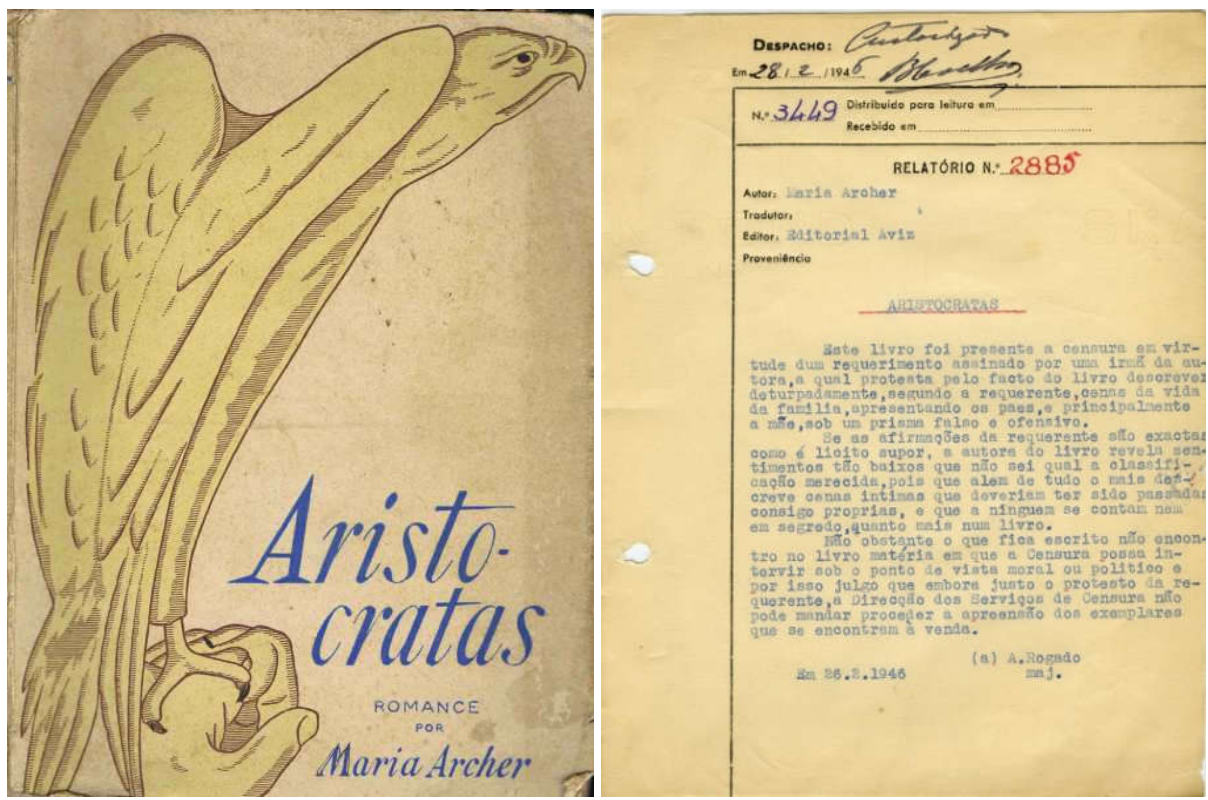

Figuras 1 e 2. Capa de Aristocratas de Maria Archer, 1945, e Relatório da Censura 2885/1946, fotografias (detalhes).

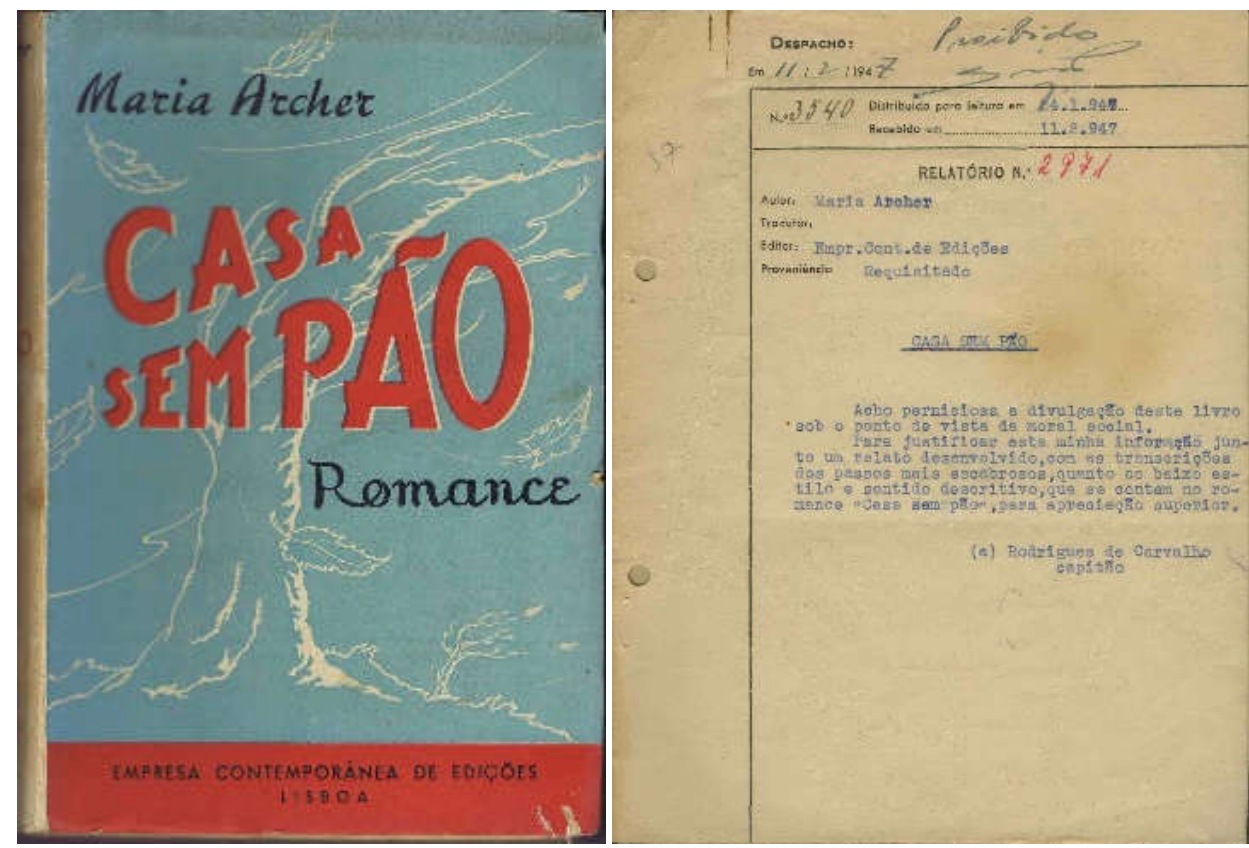

Figuras 3 e 4. Capa de Casa sem pão de Maria Archer, 1947, e Relatório da Censura 2971/1947, fotografias (detalhes).

No caso do romance autobiográfico Aristocratas (1945), a autora se indispôs com a família, que se viu representada no texto. Em 1946, a irmã da escritora encaminhou à Direção dos Serviços de Censura o pedido de apreensão da obra. O parecer do órgão relatava: "Se as afirmações da requerente são exactas, como é licito supor, a autora do livro revela sentimentos tão baixos que não sei qual a classificação merecida, pois além de tudo o mais descreve cenas intimas que deveriam ter sido passadas consigo próprias, e que a nin- 
guém se contam nem em segredo, quanto mais num livro". ${ }^{20}$ Apesar dessas ponderações críticas à autora, a decisão final da Direção dos Serviços de Censura foi pela não apreensão dos exemplares.

Com o recrudescimento político e moral do regime, a obra de Archer foi considera "inadequada" e ela passou a ser "cautelosamente acompanhada" pela Pide. Em 1947, a autora caiu novamente nas garras da censura com o livro Casa sem pão, que foi apreendido. Os despachos da Direção dos Serviços de Censura, assinados pelo capitão Rodrigues de Carvalho, indicavam que ele foi considerado como um "grave inconveniente moral":

Lisboa, fevereiro de 1947.

Acho perniciosa a divulgação deste livro sob o ponto de vista moral e social.

Para justificar esta minha informação, junto um relato desenvolvido, com as transcrições dos passos mais escabrosos, quanto ao baixo estilo e sentido descrito que contém o romance Casa sem Pão para a apreciação superior.

Este, como não podia deixar de ser, em face de texto imoral do livro, é de aberta oposição a divulgação do romance "CASA SEM PAO", que melhor lhe ficaria o título - "Livro sem moral"

A BEM DA MORAL SOCIAL, Desfecho Proibido. ${ }^{21}$

Archer reafirmava que seus escritos eram norteados pelo questionamento à condição de discriminação e submissão das mulheres. ${ }^{22}$ Sua abordagem, temáticas e a descrição narrativa enfrentavam as concepções vigentes dos papéis atribuídos aos gêneros, marcados pelos padrões apregoados pelo conservadorismo moralista do Estado Novo. Por isso, seus livros foram identificados como ousados e acintosos, sendo a escritora considerada pelos mecanismos censórios como "incômoda":

tudo o que Maria Archer dizia era proibido. Tudo o que ela escrevia, portanto, era assustador por esse motivo. A desvirginização, o aborto, o prazer sexual das mulheres, a violência masculina. O trabalho escravo que as mulheres então executavam nas suas próprias casas. A violação diária na cama do casal. A passividade ou revolta contra tudo isto. A prostituição a que tantas raparigas eram obrigadas ou apenas empurradas, por uma sociedade hipócrita, que em seguida a condenava. ${ }^{23}$

A partir de 1945, Archer se destacou pela presença em círculos literários, culturais e pela militância política, com críticas ao Estado Novo e filiação ao Movimento de Unidade Democrática (MUD), organização de oposição ao regime salazarista. Em 1949, apoiou o candidato de oposição à presidência, Norton de Matos:

\footnotetext{
${ }^{20}$ Direção Geral do Livro dos Arquivos e das Bibliotecas-PIDE/DGS Processo 3549/1946 e Relatório da Censura 2885/1946.

${ }^{21}$ Direção Geral do Livro dos Arquivos e das Bibliotecas-PIDE/DGS. Processo 3540/1947 e Relatório da Censura 2971/1947. A autora apresentou novo recurso à Direção dos Serviços de Censura em 1969, o processo foi revisto e a obra liberada com vários cortes, contendo o seguinte despacho: "Julgo, pois, que, com a condição expressa dos "cortes" apontados, possa ser autorizada a reedição do romance em causa".

22 ARCHER, Maria. Revisão de conceitos antiquados, op. cit., p. 5.

${ }^{23}$ HORTA, Maria Teresa, op. cit., p. 15.
} 
A minha modesta obra de escritora ia-se também realizando e a sua crítica pertinaz aos quadros duma sociedade decadente e descrente de si mesma situou-me, a mim, sua autora, antes mesmo de eu ter escolhido refletidamente o meu caminho, acentuou-me no campo espiritual da oposição. Eu era tida e considerada como escritora oposicionista antes mesmo de ter dito, a mim própria, que era esse, definitivamente, o meu rumo, que eu esposava, conscientemente, grande parte dos seus ideais. ${ }^{24}$

Como credenciada pelo jornal República (1953), assistiu ao julgamento do opositor ao regime Henrique Galvão (1953), fez anotações dos depoimentos, entrevistou o réu, advogados e o próprio o juiz, sinalizando com a proposta de escrever um livro sobre a questão. Devido a essa participação, passou a ser vigiada, foi interrogada pela Pide, sua casa foi invadida por agentes da polícia e suas anotações sobre o julgamento foram apreendidas. ${ }^{25}$ Denunciou o ocorrido no artigo "Um caso inédito de perseguição do pensamento", publicado na República, em 20 de outubro de 1953.

As pressões se ampliaram, ela se queixava das hostilidades de uma sociedade conservadora, do endurecimento do regime, da perseguição da Pide e da censura com a interdição dos seus livros. Com medo de uma possível prisão e sem condições de continuar suas atividades, em julho de 1955 exilou-se no Brasil. 26

\section{Resistências antissalazaristas em São Paulo: por um Portugal Democrático}

Desde os inícios do século XX, São Paulo concentrava um elevado número de imigrantes portugueses. Muitos vieram em busca de oportunidades devido às novas perspectivas geradas pela expansão econômica e industrial, outros escapando das dificuldades da vida no campo, do serviço militar obrigatório e fugindo das tensões/perseguições políticas. ${ }^{27}$

Em Portugal, os percalços políticos produziram ondas de exílios desde 1926/7, que se acentuaram depois da implantação do Estado Novo (1933). Destacavam-se entre os motivos das saídas os questionamentos ao regime, os vínculos a partidos de oposição, a falta de perspectivas profissionais, as exclusões (muito comuns nas carreiras universitárias e públicas), a censura (de artistas, jornalistas e escritores), as situações de medo e insegurança. Assim sendo, São Paulo se tornou uma possibilidade de acolhimento aos opositores do salazarismo, constituindo-se redes de apoio e recepção que envolviam partidos (PCP e PCB), associações, grupos profissionais e políticos, jornalistas, intelectuais e acadêmicos brasileiros.

Os exilados das décadas de 1950/60 se diferenciavam dos que chegaram anteriormente (1927/33, em sua maioria, de orientação republicana). A nova leva incorporava comunistas, socialistas, anarquistas, liberais republica-

\footnotetext{
${ }^{24}$ ARCHER, Maria. Eu...e mais eu, op. cit.

${ }^{25}$ Uma cópia dessas anotações foi enviada a Tomás Ribeiro Colaço, amigo exilado no Brasil, o que possibilitou a produção do livro Os últimos dias do fascismo português, publicado no Brasil em 1959.

${ }^{26}$ Ver ARCHER, Maria (entrevista). Diário de Notícias, op. cit.

${ }^{27}$ A historiografia sobre o Estado Novo português tem sido enriquecida por vários estudos e diferentes perspectivas, contudo as ações da oposição dos que se encontravam fora do país (muitos deles exilados) ainda carecem de novas investigações. Ver PAULO, Heloisa. Aqui também é Portugal, op. cit., e MARTINS, Susana, op. cit.
} 
nos e até dissidentes do próprio regime (após as eleições de 1957/58). ${ }^{28}$ Não obstante a diversidade de tendências políticas, esses exilados convergiam numa plataforma unificadora de contestação ao regime salazarista e se uniram em ações de oposição, inclusive, atuando pela imprensa. Foi o caso do grupo que fundou o jornal Portugal Democrático (inicialmente instalado na sede do Centro Republicano Português), editado entre 1956 e $1977 .{ }^{29}$

Coube a Vítor de Almeida Ramos e Manuel Ferreira Moura, ambos membros do Partido Comunista Português, a iniciativa de articulação para a criação do periódico, que no primeiro número explicitava sua proposta:

A política que pretendemos realizar e a missão que temos a cumprir são, pura e simplesmente, servir o Portugal Democrático com verdade e independência. [...] mostrar aos portugueses que se interessam por Portugal a real situação do país, destacando a cultura portuguesa; mudar a imagem do país, vencer as barreiras da censura, da falta de dinheiro e de apoio; estamos voltados para o futuro, consciente das realidades do presente e orgulhoso das grandezas do passado; aqui têm, pois, os portugueses do Brasil o seu jornal: o Portugal Democrático. ${ }^{30}$

O periódico contava com a colaboração de intelectuais, escritores, jornalistas e todo um conjunto de militantes e voluntários. Entre os editores se destacaram Adolfo Casais Monteiro, Carlos Maria de Araújo, Fernando Lemos, Jorge de Sena, João Alves das Neves, Fernando Correia da Silva, Paulo de Castro e Maria Archer ${ }^{31}$, que escreveu várias matérias de críticas ao salazarismo. O jornal teve a participação de figuras de destaque cultural e político do Brasil, bem como de autores das colônias portuguesas em África.

Pelo meio de todo um sistema de redes de contatos e apoios, o Portugal Democrático circulava em várias regiões do Brasil e em outros países como USA, Canadá, Inglaterra, França e na América Latina (Venezuela, Uruguai, Argentina), sendo o jornal de oposição, editado no exterior, de maior circulação. Apesar de censurado pela Pide, o periódico chegava clandestinamente a Portugal. ${ }^{32}$

Os editores do Portugal Democrático buscavam enfrentar a propaganda política do salazarismo conscientizando seus leitores sobre as ações e práticas do regime. Nesse sentido, várias foram as temáticas abordadas denunciando a situação política e econômica de Portugal, os horrores praticados nos campos de concentração de prisioneiros, as ações da censura, a violência, as condições da educação e das universidades, a repressão aos movimentos de estudantes e de luta pela anistia e revelando as tensões coloniais na África e Ásia, entre outras adversidades. Lavrava-se, assim, um

${ }^{28}$ Cf. PAULO, Heloisa. O exílio português no Brasil: os "budas" e a oposição antissalazarista". Portuguese Studies Review, v. 14, n. 2, Ontario, 2006-2007; SILVA, Douglas M., op. cit., e OLIVEIRA, Fábio Ruela de, op. cit.

${ }^{29}$ Ver RODRIGUES, Miguel Urbano. Portugal Democrático: um jornal revolucionário. In: LEMOS, Fernando e LEITE, Rui Moreira (orgs.). A missão portuguesa: rotas entrecruzadas. São Paulo-Bauru: Editora Unesp/Edusc, 2003.

30 Portugal Democrático, n. 1, São Paulo, jul. 1956.

${ }^{31}$ Entre os membros atuantes do Portugal Democrático identificou-se a presença de apenas quatro mulheres Maria Archer, Maria Irolinda, Manuela de Gouveia e Maria Antônia Fiadeiro, mas participantes declararam que outras se faziam presentes.

${ }^{32}$ Cf. RODRIGUES, Miguel Urbano, op. cit. 
Protesto contra todas as mentiras, violências, injustiças, crueldades, extorsões - polícia política, campos de concentração, presos políticos, eleições roubadas, desprezo pela liberdade, indiferença pelos direitos do povo e suas gloriosas tradições de independência - que, por todos os modos, num conto do vigário colossal, tem sido apresentado ao mundo inteiro como uma era de progresso, de fraternidade, de paz e prosperidade em Portugal. De esperança, de certeza mesmo, que tudo quanto infelicitou durante trinta anos a nossa pátria, sem liberdade, sem teto, sem pão para o mísero paisano e seus filhos, está no fim. ${ }^{33}$

A convergência na oposição ao salazarismo não minimizou a existência de divergências e disputas internas, com momentos de tensões e cisões que levaram ao afastamento de colaboradores. Cabe rememorar que, em março de 1963, membros do conselho de redação do periódico vinculados ao PCP vetaram um artigo de Adolfo Casais Monteiro. Em resposta, o autor, seguido por Fernando Lemos, Jorge de Sena, Paulo de Castro, Fernando Correia da Silva e Maria Archer se afastaram do conselho do Portugal Democrático.

Após o golpe civil-militar de 1964, ocorreram pressões sobre os envolvidos com o jornal, o grupo cogitou o encerramento das atividades, mas a publicação se manteve firme. Em abril de 1974, o jornal assumiu entusiasticamente a cobertura da "Revolução dos Cravos"; porém, com o retorno de muitos colaboradores, após dezenove anos de ação (totalizando 205 números impressos), o Portugal Democrático finalizou sua publicação, em 1977.

\section{Maria Archer: exílio e resistência antissalazarista}

O exílio é uma fratura incurável entre um ser humano e um lugar natal, entre o eu e seu verdadeiro lar: sua tristeza essencial jamais pode ser superada. [...] a vida de um exilado, não é mais do que esforços para superar a mutiladora da separação. ${ }^{34}$

Em Portugal, Maria Archer sofreu pressões políticas, teve obras censuradas, perdeu suas condições de subsistência, foi silenciada e condicionada ao exílio, mantendo-se afastada do seu país durante mais de duas décadas.

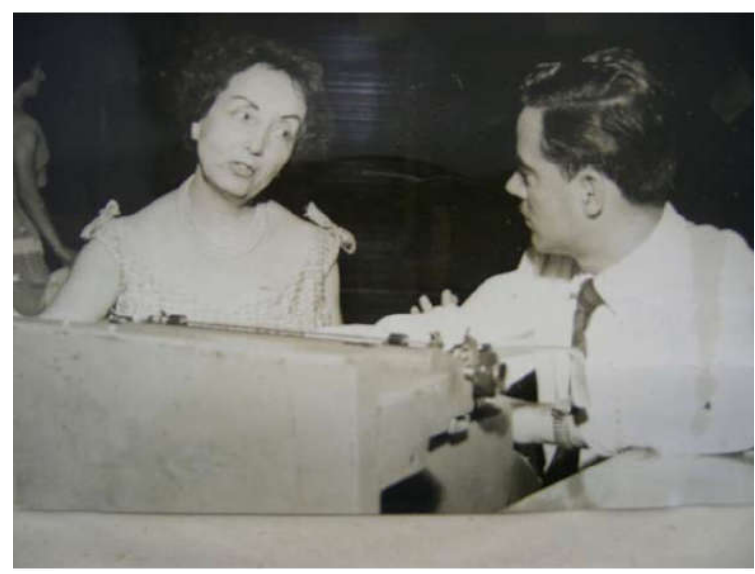

Figura 5. Entrevista de Maria Archer à Folha de S. Paulo, 1955, fotografia (detalhe).

\footnotetext{
33 Portugal Democrático, n. 4, São Paulo, nov. 1956.
}

${ }^{34}$ SAID, Edward, op. cit., p. 46 e 60. 
No exílio em São Paulo, participou ativamente de ações políticas em várias frentes e manteve sua produção constituída por livros, crônicas, artigos, ensaios, palestras, conferências e participações radiofônicas. Seus escritos e atuações se centravam na denúncia/oposição ao regime salazarista e nas questões femininas. Também buscou divulgar a cultura dos países onde viveu, apregoando a confluência histórico-cultural entre os dois lados do Atlântico (Brasil e África portuguesa).

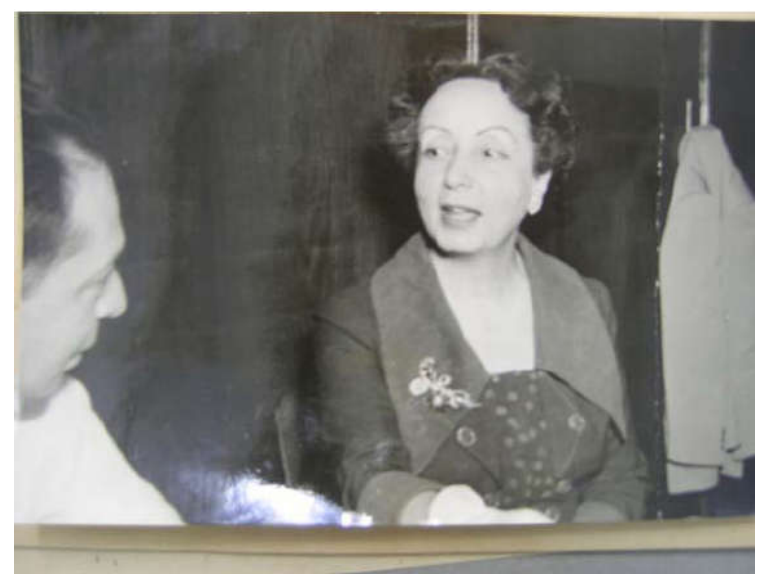

Figura 6. Entrevista de Maria Archer ao Correio Paulistano, 1956, fotografia (detalhe).

A escritora esteve sob a investigação do Deops (Departamento Estadual de Ordem Política e Social, de São Paulo) ${ }^{35}$, sendo elaborados relatórios de "observação preventiva", que permitem rastrear sua intensa militância política, como num comunicado de 1957:

Levamos ao conhecimento dessa chefia que, ainda em serviço de observação proveniente nos meios estudantis à volta da próxima visita a São Paulo do Gal. Francisco Craveiro Lopes, fomos encontrar, agindo neste mesmo setor e sobre os mesmos motivos, a comunista portuguesa Maria Archer, que, inclusive, acaba de mandar editar um livro de sua autoria sobre as gentes lusas, em diversos países do mundo.

Segundo estamos informados, na tarde do dia 8 último, Maria Archer telefonou para um dos diretores da UESP, de nome Sérgio Lessa, e em cuja presidência, à Rua Sorocaba, 48, se verificava a primeira reunião ordinária daquela entidade estudantil, solicitando-lhe que lh'a convidasse para assistir tal "meeting" estudantino, o que foi feito.

Em meio ao debates naquela reunião, Maria Archer, dizendo-se visceralmente adversária do atual Presidente de sua pátria, Gal. Francisco Higino Craveiro Lopes, sob a alegação de ter sido uma das vítimas do regime então reinante no país; e, depois de dizer que até sua residência particular houvera sido vasculhada pela polícia portuguesa, a mando do Governo luso, quando lhe furtaram vários originais de sua lavra, pediu que naquela reunião de estudantes se fizesse uma moção de protesto contra a visita do Gal. Francisco Craveiro Lopes a São Paulo, e em repúdio aos gastos excessivos feitos pelo Governo Brasileiro no acolhimento a um ditador estrangeiro. Esta moção, que ali fora redigida pelo estudante Sérgio Lessa, fora aprovada por Gilberto

${ }^{35}$ Serviço de Informações, SSP/SP, doc. 50 C-24-321, 321로 323, 1957-63. Fundo DEOPS/SP, Arquivo Público do Estado de São Paulo (Apesp). 
Rogê Ferreira, Elpídio Reali Júnior, Norma Jarnol, João Carlos Aguiar e Luiz Fernando Ribeiro da Silva, contra Joaquim Lima Neto, Firmino de tal, Henrique Bamer e João Gonçalves e uma abstenção. Satisfeita com o resultado da votação, Maria Archer prometeu escrever um livro, dentro em breve, contando a unidade, a combatividade e coragem na luta dos estudantes. ${ }^{36}$

As ações de Archer visavam atrair apoio à causa antissalazarista. Nesse sentido, em janeiro de 1959, discursou no ato organizado pela União Estadual dos Estudantes (UEE) em solidariedade ao povo cubano:

Heróis anônimos tombam dia após dia, nos porões das cadeias políticas de Salazar, enquanto uma centena de fantoches do governo vive no luxo e no conforto. A colônia portuguesa que se encontra no Brasil, talvez por ser formada na sua maior parte de indivíduos apolíticos, que para cá se dirigem e tenho a impressão que aqui se influenciam pela máquina de propaganda orientada pelo governo português, começa ultimamente a tomar consciência, e felizmente, da real situação; o mesmo não se deu quando há dois ou três anos passados para aqui se dirigiu o caixeiro viajante da ditadura general Craveiro Lopes. ${ }^{37}$

A escritora participou de várias ações e movimentos políticos, alguns de ampla audiência, como o Comitê dos Intelectuais e Artistas Portugueses Pró-Liberdade de Expressão (1958), Conferência Sul-Americana Pró-Anistia para os Presos e Exilados Políticos da Espanha e Portugal (janeiro/1960, quando aborda a temática da censura em Portugal), manifestações pró candidatura Lott-Jango (1960), II Conferência Sul-Americana Pró-Anistia para os Presos e Exilados Políticos da Espanha e Portugal (Montevidéu/1961)38, Encontro Estadual de Solidariedade a Cuba (compondo a mesa com Caio Prado Jr., Helena Silveira, José Serra e Jamil Haddad, março/1963), Debate "42 anos de fascismo em Portugal" (PUC-SP, finais de 1968). No Ato Público em Solidariedade dos Povos de Portugal e Espanha, no Cine Paramount, em 27 de maio de 1962, fez parte da mesa de discussões:

Levamos ao conhecimento dessa chefia que, segundo nossos observadores, realizou-se na manhã de ontem, dia 27, das 9:10 às 12:50 horas, no Cine-Teatro Paramount, à Avenida Brigadeiro Luiz Antonio, o anunciado ato público de solidariedade aos trabalhadores e aos povos de Espanha e Portugal.

Os trabalhos, que contaram com presença de cerca de 900 pessoas (lotando a plateia e os camarotes), foram presididos pelo Deputado Cid Franco, tendo ainda tomado assento à mesa os seguintes elementos: Dep. José Rocha Mendes Filho; Dep. Germinal Feijó; Dep. Paulo de Tarso; Dep. Jéthero de Faria Cardoso; João Louzada; Gen. Humberto Delgado; Luiz Carlos Prestes; Dr. Walter Dias (advogado da Associação dos Lavradores e Trabalhadores Agrícolas de Jales); Eng. Tito de Morais (líder do Movimento Português); Antonio Guardióla (líder do Movimento Espanhol); José Vendral (líder do

\footnotetext{
${ }^{36}$ Assunto sobre a escritora portuguesa, em São Paulo, Maria Archer. Comunicado do Serviço Secreto do Deops, 11 jun. 1957. Doc. 50-C-25-321. Fundo DEOPS/SP, Arquivo Público do Estado de São Paulo.

${ }^{37}$ ARCHER, Maria. Em Ato de Solidariedade ao Povo Cubano, promovido pela UEE (União Estadual dos Estudantes) em 24 jan. 1959. Cf. Relatório-documento 50C-24-321,321A e 323. Fundo DEOPS-SP. Arquivo Público do Estado de São Paulo.

${ }^{38}$ Cf. Relatório-documento 52-Z-0-14.284. Fundo DEOPS-SP. Arquivo Público do Estado de São Paulo.
} 
Movimento Espanhol); Prof. Ênio Sandoval Peixoto; Helena Silveira (presidente da UBE); Maurício Vasconcellos Pinheiro (presidente da UEE); Dolores Mello Vassão (secretária da Comissão Paulista Pró-Anistia aos Presos e Exilados Políticos de Espanha e Portugal); Ítala Schwartzmann (presidente da Federação das Mulheres do Estado de São Paulo); Maria de Lourdes Prestes Maia; Maria Archer (União Brasileira de Escritores); Edgar Leuenroti; Prof. Florestan Fernandes; os líderes sindicais Pedro Francisco Iovine, Gentil Neves Correia, Floriano Francisco Dezen, José Molenídio, Thimóteo Spinola e José Xavier dos Santos. ${ }^{39}$

As questões que envolviam as mulheres portuguesas se fizeram presentes nas lutas de Maria Archer. Em abril de 1960, no Centro Republicano Português de São Paulo, a escritora proferiu a conferência "Presença da mulher na paisagem social portuguesa". Já em 1963, juntamente com Maria Fernandes, Maria Ermelinda, Janette A. Pereira e Maria Aldina, Maria Archer fundou a "sucursal" da União das Mulheres Portuguesas (UMP), da qual foi eleita presidente, sendo a iniciativa noticiada no Portugal Democrático: "Filiado ao Movimento das Mulheres Democratas Portuguesas, e com ligações estabelecidas no Uruguai, Buenos Aires, Mar del Plata, Rio, Recife, fundou-se recentemente em São Paulo uma sucursal da União das Mulheres Portuguesas. [...] Saudamos calorosamente o novo elemento de combate ao fascismo e cumprimentamos as senhoras portuguesas que o iniciaram". ${ }^{40}$

No Ato Público de Solidariedade às Presas Políticas Portuguesas, concorrido evento patrocinado pela UMP, em 4 de março de1964, no auditório da Biblioteca Municipal de São Paulo, Archer expôs a situação das mulheres encarceradas na fortaleza subterrânea de Caxias:

A situação trágica, desesperadora dessas presas, há longos anos sequestradas do mundo nos cárceres salazaristas, está atraindo a atenção internacional. São mulheres das mais diversas camadas sociais, desde a intelectual, em que há escritoras, engenheiras, artistas, professoras, médicas, etc., às operárias e camponesas. Nenhuma foi condenada por atos mais graves que pichar paredes, espalhar jornais e panfletos, aliciar elementos para tentativas de greve, tomar parte de agrupamentos clandestinos, seja de intelectuais, escolares ou operários assinar manifestos e cartas mimeografadas, viajar para o exterior para os congressos de juventude ou femininos. Nenhuma foi condenada por sabotagem, terrorismos, assaltos ou atos semelhantes. Contudo, estão há anos trancadas numa fortaleza subterrânea, sem ver a luz do sol, e pior ainda, sem esperança! Para elas, uma única esperança fulgura - somos nós, senhoras e senhores, sois vós, sobretudo vós, brasileiros. É para os brasileiros que se estendem as mãos súplices emanadas nas sombras da fortaleza de Caxias. ${ }^{41}$

Entre os artigos e crônicas produzidos pela autora se destacam os publicados em O Estado de S. Paulo ${ }^{42}$, no qual contribuiu no Suplemento Literatu-

\footnotetext{
${ }^{39}$ Relatório Deops, 28 maio 1962. Documento 50-E-29-50. Fundo DEOPS-SP. Arquivo Público do Estado de São Paulo.

${ }^{40}$ União das mulheres portuguesas. Portugal Democrático, n. 75, São Paulo, ago. 1963, p. 5.

${ }^{41}$ ARCHER, Maria. Portugal Democrático, n. 82, São Paulo, abr. 1964, p. 4. Na mesma página o jornal colocava em destaque uma coluna intitulada Heroínas e mártires na luta contra o fascismo português, na qual listava mulheres mortas e presas políticas, assunto pouco abordado no periódico.

${ }^{42} \mathrm{O}$ Estado de S. Paulo foi o único dos grandes jornais brasileiros que manteve uma plataforma de oposição ao salazarismo, tendo acolhido nos seus quadros vários jornalistas e intelectuais exilados; além de Archer, destacaram-se Miguel Urbano Rodrigues, João Alves das Neves, Vitor da Cunha Rego, Carlos Maria de
} 
ra e Arte (6 ensaios em 1956, que discutem comparativamente a formação histórica e cultural de Angola e Brasil); de forma mais expressiva e constante destaca-se sua participação no Suplemento Feminino, totalizando cerca de 120 colunas (de 1955 a 1957), que, entre assuntos variados, priorizaram as crônicas de memória e as referentes à África. ${ }^{43}$

Maria Archer também escreveu em outros periódicos como A Gazeta, Semana Portuguesa e Portugal Democrático (1955 a 1963), do qual foi uma das articuladoras. Seus artigos demonstravam erudição, cultura e eram marcados pela atuação política visavam mobilizar, convencer e envolver a opinião pública na luta antissalazarista.

No Portugal Democrático, Archer publicou 12 crônicas (1956-1963) ${ }^{44}$ abordando temáticas políticas, com destaque para as denúncias sobre a censura e falta de liberdade de expressão. Apontava o desconhecimento e ocultamento da censura vigente nos países ibéricos, particularmente, em Portugal deixando seu testemunho de ter dois dos seus livros de ficção apreendidos pela polícia política -, bem como as consequências da censura ao processo criativo e seus malefícios à literatura portuguesa. No artigo "A censura à imprensa e ao livro", em outubro de 1956, rememorava: "meus livros foram apreendidos sem a mínima justificação do acto e sem sequer me ser dada resposta aos pedidos que fiz para que essa explicação me fosse fornecida. [...] a simples existência da censura destrói uma geração literária. [...] A nossa situação é tão dura e dolorosa que o livro chega a ser apreendido em casa, ainda em original inacabado, em cima da secretaria, como me aconteceu". ${ }^{45}$

\footnotetext{
Araújo, Santana Mota e, durante certo período, Henrique Galvão (que se dedicava a uma exótica coluna sobre os safáris na África). Alguns escreviam artigos e/ou crônicas no Suplemento Literário.

${ }^{43}$ Nessas crônicas se observam alguns eixos temáticos: crônicas de memória, sobre a África e assuntos variados. Nas crônicas de memória, a autora criticava a condição feminina, os mecanismos e abusos do poder masculino, os acordos matrimoniais movidos por interesses, os códigos de posturas restritivos às viúvas, a ditatura da estética e o culto à beleza e à juventude; retratava o cotidiano feminino, as mulheres das aldeias e as cruéis relações entre patroas e criadas. As crônicas sobre a temática africanista visavam ampliar o conhecimento sobre África, apresentado aspectos sociais, étnicos, políticos, culturais e históricos, focalizando as diversas experiências das mulheres africanas. Por fim, abordando temáticas variadas, demonstrava preocupações sociais, discutia questões como desigualdades, pobreza, desamparo dos trabalhadores na doença e na velhice, apresentava a comunidade portuguesa (associações, clubes, círculos literários, hospitais, asilos), iniciativas humanitárias/caritativas (com destaque para a Cruz Vermelha) e questões culturais (teatro, documentários, literatura e língua portuguesa), entre outros assuntos. Ver BATISTA, Elisabeth, op. cit.

${ }^{44}$ ARCHER, Maria. A censura à imprensa e ao livro (out. 1956), Um vencido (jan. 1957), Carta aberta a Sua Majestade Britânica Isabel II (fev. 1957), Eu e "A Voz" (abr. 1957), Eleição de candidato único (maio 1957), Cai sobre nós esta vergonha, mulheres - I (dez. 1958) e II (jan. 1959), Somoza, Salazar e CIA (jul. 1959), A revolução áurea (out. 1960), Avacalhar e portugalizar (set. 1961), Brasil, fronteira da África (set. 1963) e Símbolo e mito do 5 de Outubro (out. 1963). Portugal Democrático, op. cit., 1956-1963.

${ }^{45} \mathrm{Idem}$, A censura à imprensa e ao livro. Portugal Democrático, op. cit., p. 5 e 6
} 

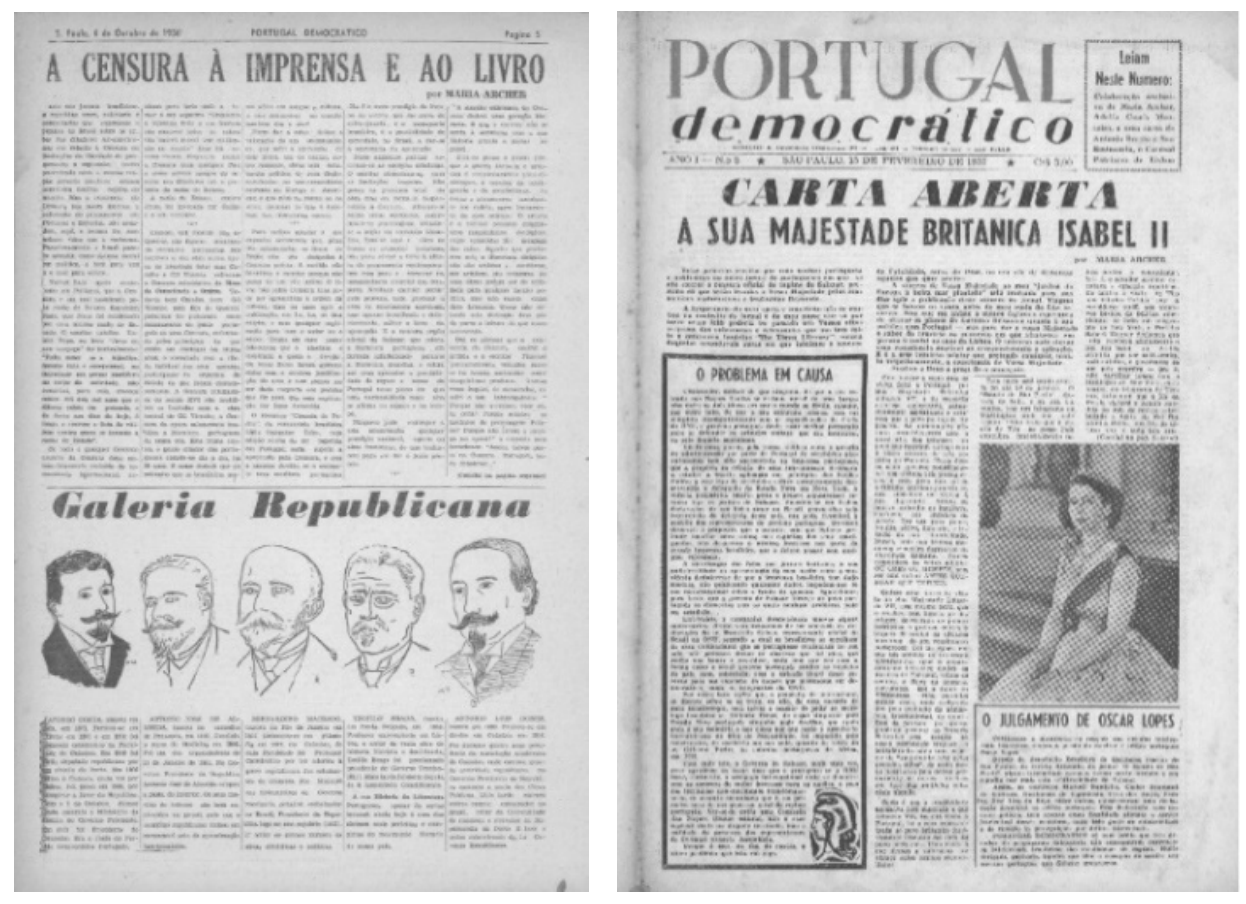

Figuras 7 e 8. Artigos de Maria Archer publicados em Portugal Democrático, n. 4, out.1956, e n. 8, fev. 1957, fotografias (detalhes).

Em seus escritos. Maria Archer assumia um discurso de acusação, buscando conscientizar os leitores sobre a real situação e as atrocidades cometidas pelo governo salazarista. No artigo "Carta aberta a Sua Majestade Britânica Isabel II", de fevereiro de 1957, utilizou a estratégia narrativa de uma carta dirigida à soberana inglesa em visita a Portugal. Nele descrevia a situação de miséria vivenciada pelo povo, as ações de opressão e censura vigentes; também denunciava a conivência do governo britânico com as atrocidades da ditatura salazarista:

São 30 anos de ditadura em que as forças e os fuzilamentos não se fizeram sentir, mas a dominação se processou pela opressão do exército, espionagem e torturas da polícia, cerceio das liberdades políticas e civis e jurídicas, exílios e internamentos em campos de concentração africanos, com ou sem julgamento, e mesmo a prisão perpétua, "como medida de segurança", para acusados absolvidos nos tribunais. A censura postal, a censura à imprensa, o saque de livros e manuscritos de cassados autores, a proibição de greves, de reunião, de associação, de eleições livres, de pluralidade partidária na política, o condicionamento econômico, fecharam o circuito opressor. São 30 anos em que as forças e fuzilamentos não se fizeram sentir, mas em que se trituraram adversários sob pressões econômicas. Comissões e perseguições, exílios, torturas policiais, julgamentos, assassinatos nas prisões, vexames contínuos, ameaças e intimidações, instalando-se a espionagem política no lar e despedaçando-se nessa engrenagem os afectos familiares sob suspeitas e delações. ${ }^{46}$

\footnotetext{
${ }^{46}$ Idem, Carta aberta a Sua Majestade Britânica Isabel II". Portugal Democrático, n. 8, op. cit., p. 1, 2 e 4.
} 
Apesar da censura do governo salazarista ao Portugal Democrático, o artigo teve repercussões em Portugal. No jornal $A$ Voz foi publicado o texto "Coisas ignóbeis" (26 fev. 1957), identificando como "ignóbeis" o periódico e a própria Maria Archer, que respondeu em "Eu e "A Voz". ${ }^{47}$ Tendo como mote a visita do presidente português Craveiro Lopes ao Brasil, no artigo "Eleição de candidato único"48, de maio de 1957, Archer denunciou as falcatruas das eleições em Portugal que ocorriam "sem fiscalização, sem disputa, verdadeira comédia eleitoral", o que tornava "Craveiro Lopes um usurpador, ilegalmente nomeado e empossado pelo ditador Salazar num posto a que o elevaram através das manigâncias duma eleição de candidato único". Apontava, ainda que Craveiro vinha em missão propagandista do regime salazarista, ditadura vigente havia mais de 30 anos.

Nos artigos "Cai sobre nós esta vergonha, mulheres - I e II"49, de dezembro de 1958 e janeiro de 1959, ela comentava a falta de apoio feminino nas lutas de oposição ao regime, apesar de apontar a existência de exceções, e clamava por maior adesão de esposas, filhas e mães na resistência ao salazarismo. Em "Somoza, Salazar e CIA", de julho de 1959, construindo paralelos entre as arbitrariedades das ditaduras de Somoza e Salazar, denunciava a situação de miséria, a ausência da liberdade de expressão, a opressão e as torturas impetradas pelo salazarismo:

Dou testemunho do que vi. Mas sei mais do que o pouco que vi, sei de certeza que há milhares de mulheres e homens torturados, deformados, humilhados, envelhecidos, assassinados, sumidos em ignotos cemitérios pela polícia salazarista. [...] Quantos presos desapareceram, na PIDE, no Porto, como se tivessem ido para o campo de concentração do Tarrafal? Nunca mais há notícias deles. Desapareceram... que a terra lhes seja leve e o seu nome perdure em nossa memória! ${ }^{50}$

Em “A revolução áurea”, de outubro de196051, elaborou uma retrospectiva histórica sobre as lutas pela República em Portugal; a temática retornou em "Símbolo e mito do 5 de outubro", de outubro de 1963. ${ }^{52}$ Já em "Avacalhar e portugalizar", de setembro de 1961, comentava a obra Segredos de Estado, de J. R. Tournoux, sobre a vida de Charles de Gaulle e os comentários do governante sobre as desilusões nacionais com a perda de prestígio internacional, como aconteceu anteriormente com Portugal. Citando Roger Vailland, no premiado livro A lei, explicava o uso do termo "portugalizar":

AO LEITOR: Ainda há quem se recorde de que o termo "portugalizar" significava, há anos, efervescência revolucionária, convulsão política, paixão e anarquia, patriotismo exaltado, mas de nenhum modo avacalhamento, desinteresse ou renúncia. Esses são os trunfos de Salazar, os seus frutos opimos. Ele conquistou mais essa gloria no seu palmarés. Hoje, "portugalizar", e é o general De Gaulle quem o diz, significa o desinter-

\footnotetext{
${ }^{47}$ Idem, Eu e "A Voz". Portugal Democrático, n. 10, op. cit., p. 1 e 6.

48 Idem, Eleição de candidato único. Portugal Democrático, n. 11, op. cit., p. 1 e 4.

${ }^{49}$ Idem, Cai sobre nós esta vergonha, mulheres - I e II. Portugal Democrático, n. 19 e 20, op. cit., p. 8 e 5, respectivamente.

${ }^{50}$ Idem, Somoza, Salazar e CIA. Portugal Democrático, n. 26, op. cit., p. 6.

${ }^{51} \mathrm{Idem}$, A revolução áurea. Portugal Democrático, n. 35, op. cit., p. 6 e 7.

52 Idem, Símbolo e mito do 5 de outubro. Portugal Democrático, n. 76, op. cit., p. 8.
} 
esse dum povo que se "avacalha". Por isso é que muitos separam a ALMA DE SUA PRÓPRIA PÁTRIA PARA A ENTREGA A OUTRA. São portugueses que não se deixam "portugalizar". 53

Além dos artigos e crônicas, no exílio Maria Archer publicou os livros Terras onde se fala português (1957), África sem luz (1962), Brasil, fronteira da África (1963). Nessas obras priorizou temáticas africanas e as relações BrasilÁfrica. O livro Os últimos dias do fascismo português veio a público em 1959. Nele, ela focalizava o julgamento do capitão Henrique Galvão (em dezembro de 1952 e março de1953), acusado de conspiração contra o governo de Salazar. Como já dito, Maria Archer acompanhou as sessões no tribunal, fez anotações e entrevistas (com o réu, advogados, testemunhas e o próprio o juiz), coletando informações. Contudo, a escritora foi convocada pela Pide e teve suas anotações apreendidas, sendo esse um dos motes do seu autoexílio (1955). Porém, como parte dos seus escritos tinham sido enviados para Tomás Ribeiro Colaço, no Brasil, Archer se empenhou na escrita e publicação do livro.

Nele, a escrita contundente objetivava envolver os leitores, sensibilizando-os sobre as arbitrariedades judiciais e crueldades do sistema salazarista. Para tanto, a estratégia narrativa se centrou na metáfora teatral, identificando o julgamento como um espetáculo, um simulacro: "estamos em pleno teatro, e do dramático, direi mesmo da tragédia" ${ }^{54} \mathrm{O}$ tribunal era o cenário, no qual os participantes desempenhavam papéis com roteiros pré-definidos e marcados pelas metáforas da guerra e da luta. O protagonista central era o capitão Henrique Galvão: “É ainda um animal lutador. Encara os juízes como adversários a quem não pede misericórdia. Está desarmado em frente de inimigos que têm por si a força da Nação, está condenado e vencido antes da batalha, mas é evidente, e clamante, que, em medida humana, é superior aos seus contrários". ${ }^{55}$

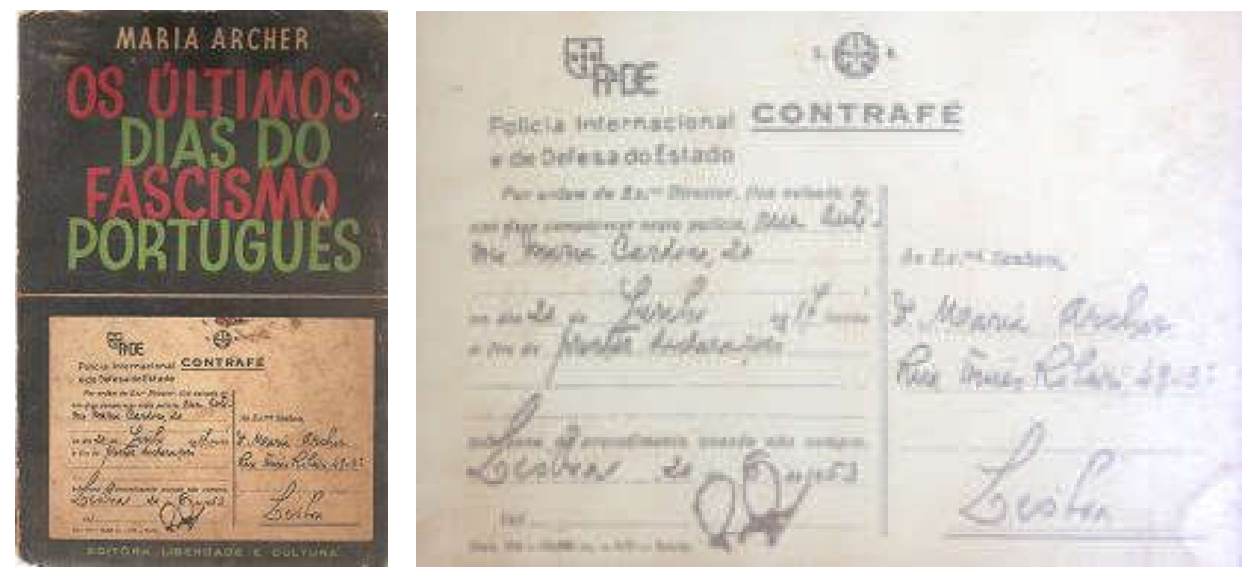

Figuras 9 e 10. Capa de Os últimos dias do fascismo português de Maria Archer, 1959, e contrafé da Pide, fotografias (detalhes).

\footnotetext{
${ }^{53}$ Idem, Avacalhar e portugalizar. Portugal Democrático, n. 46, op. cit., p. 7.

${ }_{54}$ Idem, Os últimos dias do fascismo português. São Paulo: Liberdade e Cultura, 1959, p. 89.

55 Idem, ibidem, p. 77.
} 
Os sentidos políticos da obra presentes no discurso de denúncia se encontram marcados por referências emocionais e afetivas. A própria capa foi ilustrada com a contrafé da Comissão de Censura da Pide, convocando autora a prestar declarações. Objetivando desmascarar as tramas de poder, a narrativa denunciava as injustiças, a falta de liberdade de expressão centrada num sistema estruturado na repressão política, na violência e na censura, da qual a própria autora foi vítima.

\section{Uma precursora da participação da mulher na oposição ao salazarismo}

Na participação feminina nas ações de resistência ao salazarismo, cabe destacar a atuação de Maria Archer, que através de seus escritos e palestras denunciou o regime. ${ }^{56} \mathrm{Na}$ sua trajetória, no exílio em São Paulo, pode-se atentar para duas etapas: entre 1955-1963, período marcado pela militância e ampla produção intelectual; já entre 1964-1979, observa-se a diminuição de produtividade e afastamento. Essas mudanças podem estar relacionadas ao contexto político repressivo pós-golpe de 1964, às tensões internas na equipe do Portugal Democrático, com o afastamento de vários colaboradores (entre eles, Maria Archer), e também a doença e avanço da idade.

No seu exílio, Archer buscou viver do seu ofício, mas, na década de 1970, seus ganhos eram insuficientes para custear os tratamentos de saúde. Em 1973, queixava-se ao sobrinho (Fernando de Pádua) das dificuldades enfrentadas e pedia que ele solicitasse uma autorização para o seu retorno à Portugal. Ela só conseguiu voltar em abril de 1979, já com 80 anos e saúde muito abalada; em Lisboa ficou asilada no Lar Santa Maria de Marvila, vindo a falecer em janeiro de 1982.

A posição do exilado aviva desejos de partilhar experiências marcadas por sentimentos e memórias, podendo desencadear ações e registros através de textos, ainda mais quando o oficio praticado é o da escritura, gerando narrativas de luta, denúncia e ativismo político. ${ }^{57}$ Dessa forma, Maria Archer atuou, assumiu a causa antissalazarista, escreveu e denunciou as atrocidades deste regime. Sua produção literária de Archer visava inspirar questionamentos aos papéis tradicionais das mulheres, além de denunciar e criticar o regime salazarista. As ações da censura sobre a trajetória da escritora foram basilares. Ela foi estigmatizada pelos mecanismos censórios, considerada como "dissonante", "incômoda" e "inconveniente". Dessa forma, o regime, além de censurá-la, tirou-lhe os meios de subsistência e levou-a ao exílio de mais de vinte anos; mais ainda, cortou seus vínculos com os leitores e a empurrou para o "esquecimento".

\footnotetext{
${ }^{56}$ A historiografia sobre a oposição ao regime salazarista não tem atentado ao protagonismo feminino, invisibilizando as atuações e lutas das mulheres. Camponesas e operárias participaram de protestos e greves, denunciaram a carestia, altos custos, racionamentos e falta de gêneros. Mulheres profissionais, intelectuais e artistas se manifestaram, outras participaram de partidos políticos, associações, organizações e comissões, integraram oposições de diferentes vertentes e, ainda outras, se assumiram como feministas e pacifistas. Assim sendo, frente ao estatuto de desigualdade de gênero que caracterizou o regime salazarista, cabe observar as especificidades nas formas das ações, reivindicações e lutas femininas, sendo um desafio reverter o estatuto de invisibilidade dessas experiências de luta. Ver GORJÃO, Vanda. Mulheres em tempos sombrios: oposição feminina ao Estado Novo. Lisboa: Imprensa de Ciências Sociais, 2002.

${ }^{57}$ Cf. SARLO, Beatriz, op. cit., p. 189.
} 
Esta investigação enfrentou o desafio de focalizar a trajetória combatente de Maria Archer. Contudo, apesar das tentativas de recuperação da sua obra e vida, ainda resta muito para que seja conhecida e reconhecida. Também se mantém a percepção de que muito ainda precisa ser pesquisado no sentido de dar luzes às lutas de resistência ao salazarismo dos que foram exiliados e que de longe se articularam na causa oposicionista, e, entre esses, dar vozes às mulheres que atuaram, escreveram e denunciaram as atrocidades do regime.

Artigo recebido em 10 de fevereiro de 2021. Aprovado em 20 de março de 2021. 